Health \& Medicine | Dr Stephen Bartelmez

\section{Could stem cells offer a viable treatment for retinopathy?}

\begin{tabular}{|c|c|c|}
\hline $\begin{array}{l}\text { Diabetes is a growing global } \\
\text { epidemic, with over } 400 \text { million } \\
\text { affected and cases expected } \\
\text { to double in the next } 10 \text { years. } \\
\text { Retinopathy, or damage to } \\
\text { the blood vessels in the retina, } \\
\text { occurs in most patients with } \\
\text { type } 1 \text { diabetes and } 75 \text { per cent } \\
\text { of patients with type } 2 \text { diabetes, } \\
\text { leading to vision loss for many. } \\
\text { BetaStem Therapeutits is a stem } \\
\text { cell therapy company led by Dr } \\
\text { Stephen Bartelmez. Their aim } \\
\text { is to treat diabetic retinopathy } \\
\text { by using the bod's o onn stem } \\
\text { cells to repair the damage to } \\
\text { retinal blood vessels caused } \\
\text { by diabetes. }\end{array}$ & $\begin{array}{l}\text { he macula is a part of the retina, } \\
\text { located at the back of the eye. } \\
\text { Although very small (about } 5 \mathrm{~mm} \\
\text { in diameter), it is responsible for most } \\
\text { aspects of our vision, including colour } \\
\text { vision and the fine detail of what we see. } \\
\text { Diabetic macular oedema is a swelling } \\
\text { of the retina as a result of fluid leakage } \\
\text { from damaged blood vessels within } \\
\text { the macula caused by the diabetes. In } \\
\text { addition, macular ischemia (inadequate } \\
\text { blood supply) can eventually result in } \\
\text { diabetic retinopathy ( } \mathrm{DR} \text { ), or damage } \\
\text { to the blood vessels at the back of } \\
\text { the eyes. DR is one of the leading causes } \\
\text { of blindness in adults, and currently there } \\
\text { is no effective treatment to repair cells } \\
\text { and blood vessels damaged as a result } \\
\text { of the disease. }\end{array}$ & $\begin{array}{l}\text { In healthy people, blood vessels are } \\
\text { constantly regenerated by cells derived } \\
\text { from circulating CD } C \text { 34+ stem cells. } \\
\text { These stem cells are generated in the } \\
\text { bone marrow and released into the } \\
\text { bloodstream and express the protein } \\
\text { CD34+ on their surface. They divide } \\
\text { and mature into all nine types of blood } \\
\text { cells plus give rise to another cell type, } \\
\text { endothelial cells, the building blocks } \\
\text { of all blood vessels. The stem cells and } \\
\text { endothelial cells migrate to lesions } \\
\text { on blood vessels and facilitate repair. } \\
\text { However, during the course of diabetes, } \\
\text { the patient's CD } 34+\text { stem cells become } \\
\text { dysfunctional: they can no longer give } \\
\text { rise to endothelial cells or regulate repair } \\
\text { of damaged blood vessels, both in } \\
\text { the retina, and in the rest of the body. }\end{array}$ \\
\hline
\end{tabular}

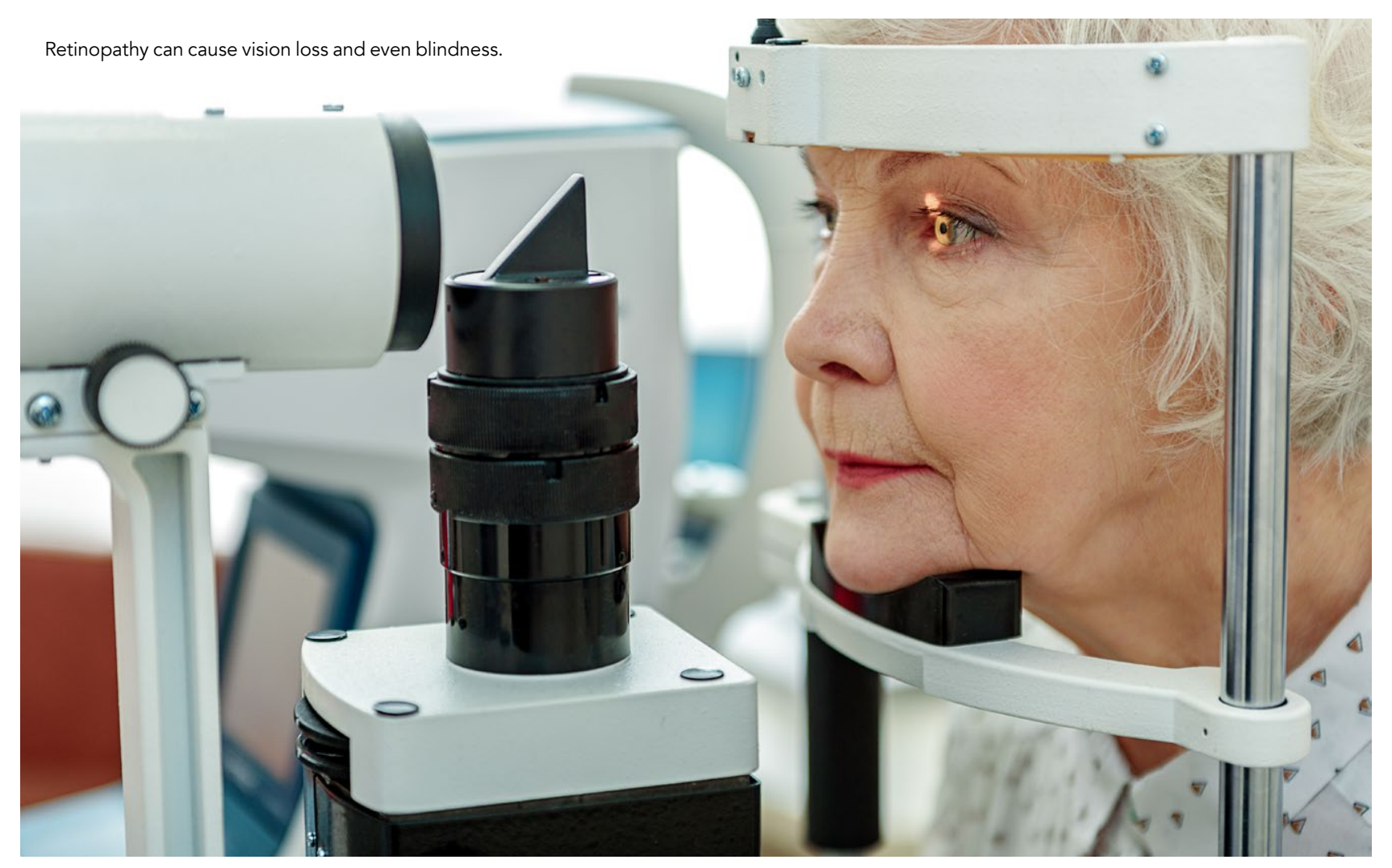

\title{
Diabetic Retinopathy
}

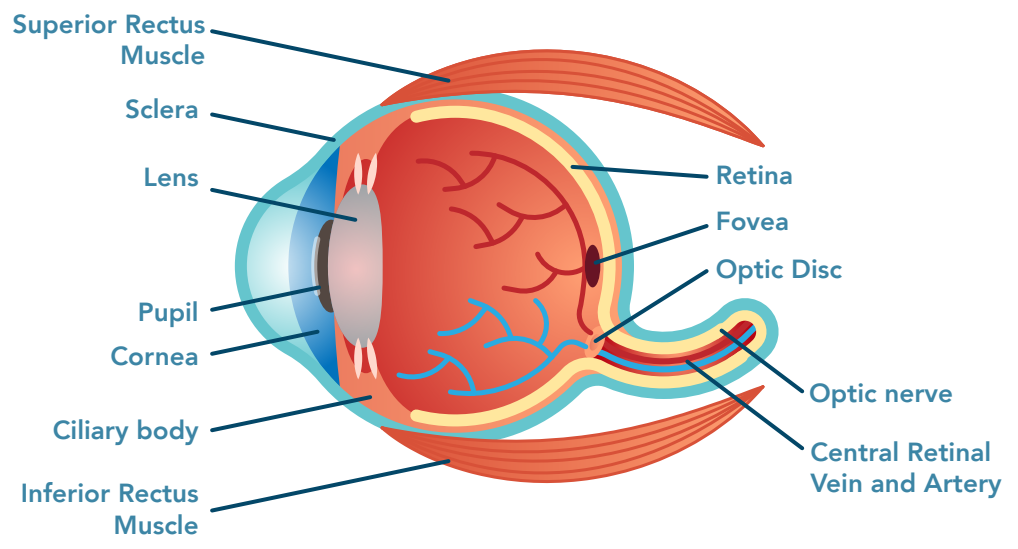

Healthy Eye

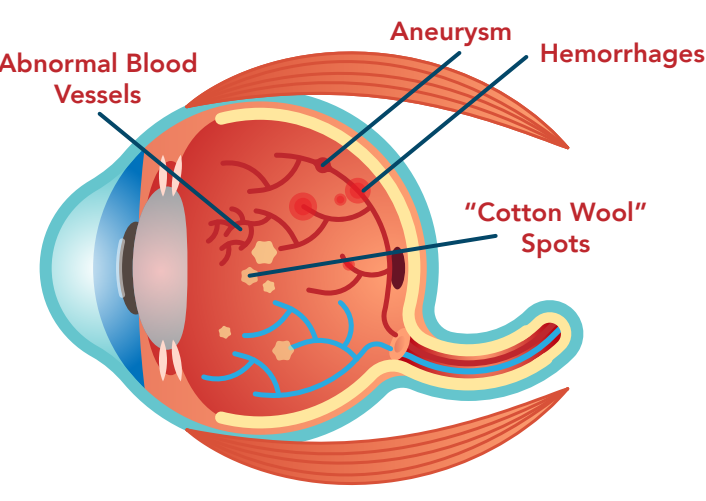

Diabetic Eye
STEM CELLS AND TRANSFORMING

GROWTH FACTOR BETA 1 GROWTH FACTOR BETA 1

haematopoietic stem cells in a process

known as haematopoiesis. This takes

place in the bone marrow, and in a healthy

adult, approximately 50 to 70 billion new

blood cells of nine different types are

produced each day. To generate all these

cells requires a complex series of events.

involving many positive and negative

signals from the surrounding tissue as
as within the stem cells themselves.

as within the stem cells themselves.

Transforming Growth Factor beta (TGF- $\beta 1$ ) is a small protein secreted by many cells in the body. Classified as a cytokine (a type of small protein important in cell signalling in blood and regulator of haematopoiesis. TGF- $\beta 1$ finely inhibits cellular divisions at major cellur checkpoints. Their work has helped elucidate the key roles of TGF- $\beta 1$ in stem cells in human blood and bone marrow.

TGF-p1 CONTROLS ALL STAGES OF HAEMATOPOIESIS

Using blood samples taken from mice as well as humans, the scientists were able to separate CD34+ stem cells from other blood cells present and grow them in the lab. Next, by treating the cells ex vivo with an antisense phosphorodiamidate morpholino ilgoht (PWO) the scientists could inhibit TGF-p1 for a short period of time in the stem cells. A PMO is a small DNA
analogue which temporarily blocks
The team found that TGF- $\beta 1$ regulates mouse and human blood stem cells in the lab and in the body in a number of ways.

the stem cells from making a targeted protein. The scientists studied different techniques to deliver PMO into cells which included syringe loading, micro injection, and by combining the PMO with fat molecules containing a positive TGF- 1 1 PMO best method for uptake of TOF $\beta 1$, to be unassisted entry. Thus CD43t PMOs overightabated with the during which time the TGF- $\beta 1$-PMO was

taken up by endosomes on the surface of the stem cells. The temperature of the Incubation as well as the concentration

This technique actually transiently inhibits the TGF- $\beta 1$ in the CD34+ stem cells. It acts as a switch to first inhibit the TGF-p then the stem cell reacts to this inhibition by upregulating the TGF- $\beta 1$ gene mRNA TGF-p1. Next, the PMO is efluxed from the stem cell causing
protein production.

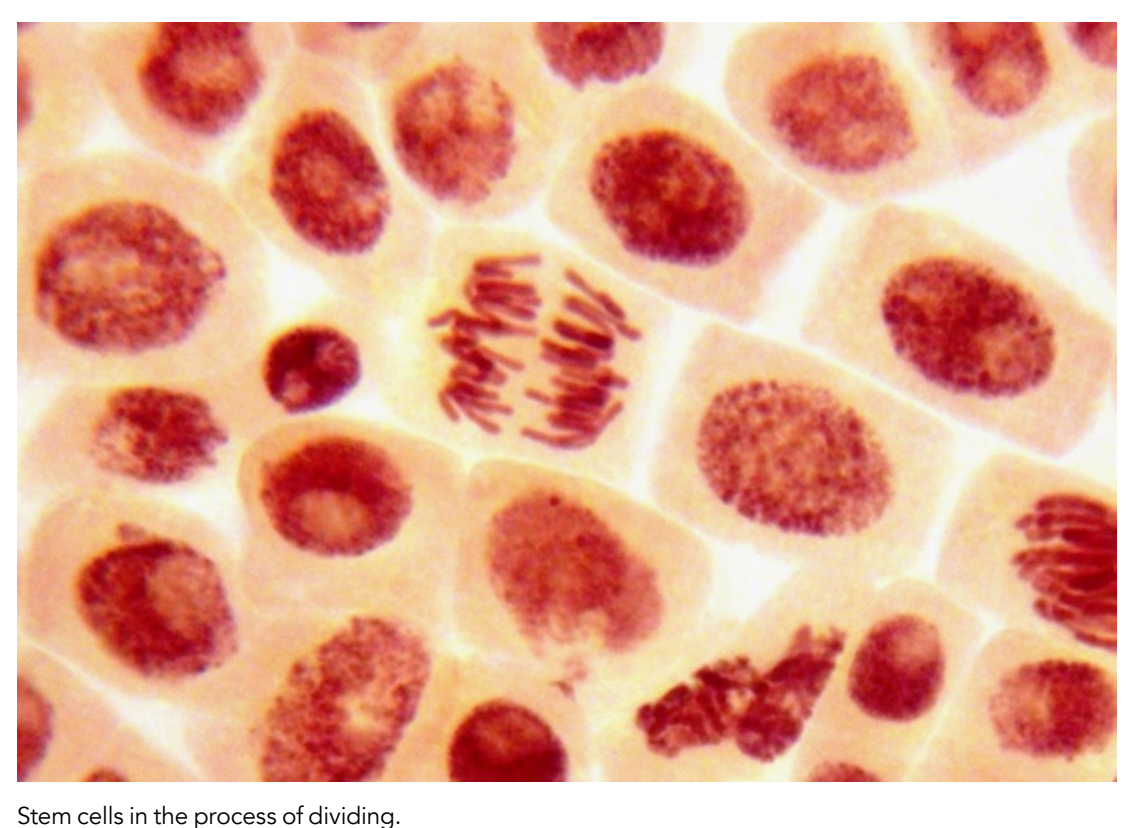


The protein was found to have many to: stimulate or prevde the ability dividing: promote cells to self-destruct or differentiate (change to another cell type); or prevent these molecula pathways from occurring. One key finding was that transient TGF- $\beta 1$ inhibition induces a balance between CD34+ cell growth, division, maturation, and periods of cell inactivity.

In humans, Dr Bartelmez identified three markers of enhanced stem cell activity that increase atter PNO treatment of stem cells: 1) increased levels of CXCR4, a protein necessary for stem cell homing and adhesion, 2) increased Nitric oxich production, which is required for cell cells to migrate and repar vasy o CD34t

The group also studied how long-term CD 34 + haematopoietic stem cells were able to regenerate and repopulate the bone marrow in mice after inhibition of TGF- $\beta 1$. They found that after lethal irradiation, they were able to use as few as sixty of these cells to rescue mice from death $(>20,000$ untreated stem cells were required to achieve the same result). In addition, they found that when the retin of mice was injured due to insufficient blood flow, and the TGF- $\beta 1-P M O$ treated CD34+ stem cells were introduced into the eye, the recruitment of diabetic CD34t cells to injured retinal capillaries dramatically increased when compared to

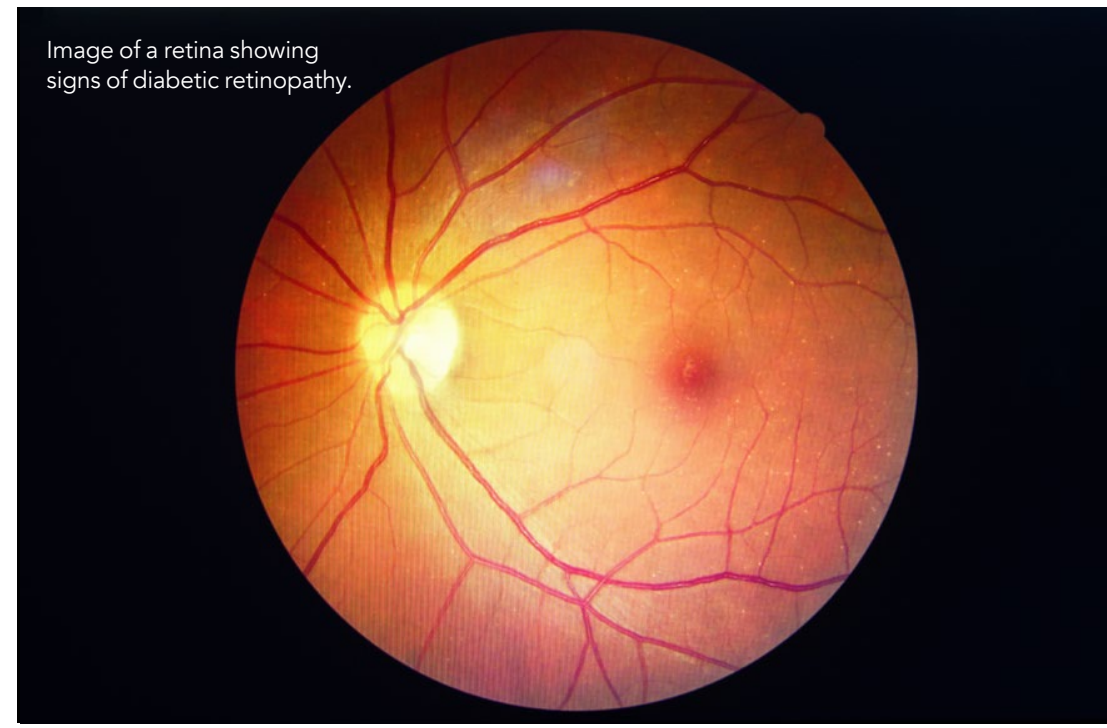

TGF- $\beta 1$ helps to maintain the balance between CD34+ cell growth, division, maturation, and periods of cell inactivity.

\section{DIABETIC RETINOPATHY:} MOVING TOWARDS A CURE The goal of BetaStem Therapeutics is to use the diabetic patient's own CD $34+$ to treat their retinopathy. They aim to do this by first isolating the CD34+ stem cells from the patient's blood and then correcting the dysfunctions in the CD34+
stem cell ions by temporarily inhibiting stem cell ions by temporarily inhibiting the patient's TGF- $\beta 1$ by incubating
the CD34+ cells for 16 hours ex vivo the CD34+ cells for 16 hours ex vivo with $\mathrm{PMO}$. This process rehabilitates the $\mathrm{CD} 34+$ stem cells which are the (ntrod bind and repair the damaged blood

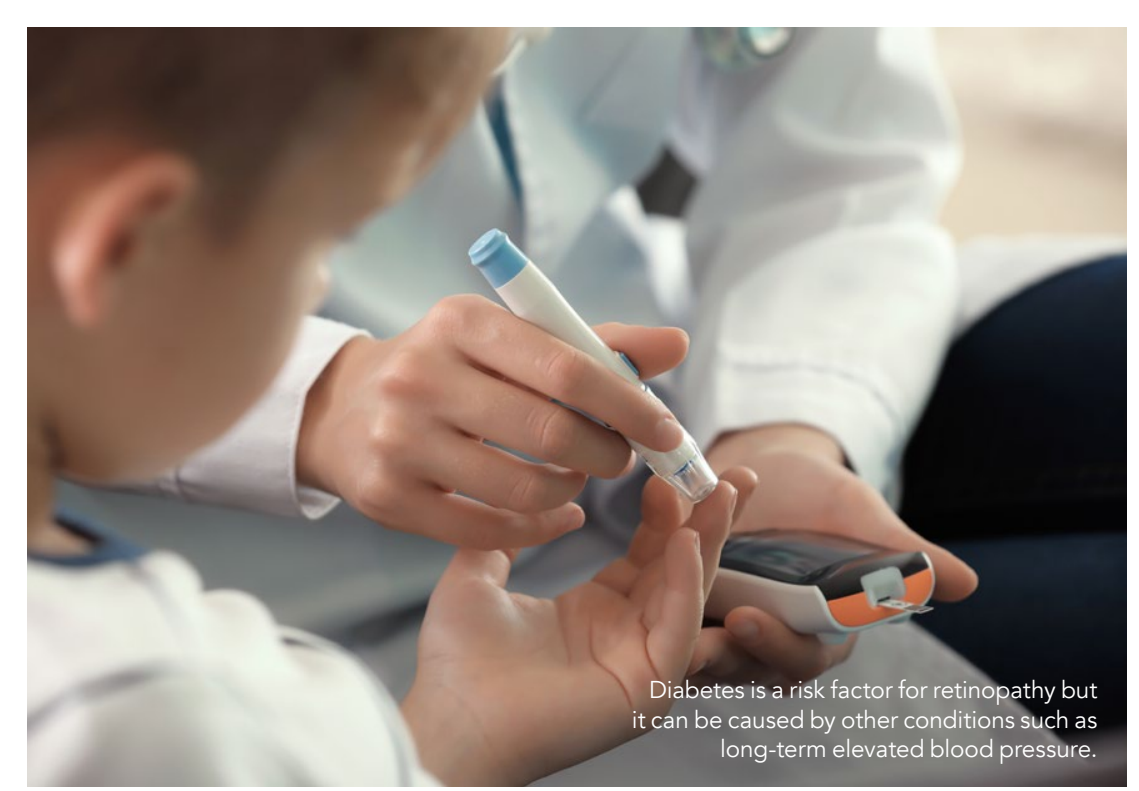

vessels in the retina. The use of PMO The due to its ability to enter haematopoietic stem cells and transiently inhibit TGF- $\beta 1$ signalling. itself: they merely bind to the TGF- $\beta$ 1mRNA and block it from translation to the protein. The half-life of the PMO is shor and the stem cell rapidly effluxes the PMO-mRNA complexes. The molecules

Transient, or brief, inhibition of TGF- $\beta 1$ may lead to the treatment of other vascular complications and could potentially improve current bone marrow poses a very low risk of adverse events. However, challenges remain, particularly when it comes to the selection of animal models that can help predict the human response to this treatment.

BetaStem Therapeutics is now preparing to test TGF- $\beta 1$ inhibition in diabetic

patients for the first time in a clinical trial. The next goal for the company will be the further study TGF- $\beta 1$ in haematopoietic stem cells. Moving forward they will develop culture conditions in which cell division of latent stem cells is stimulated prevented, in the presence of either TGF-
$\beta 1-P M O$ or TGF- $\beta 1$-inhibiting antibodies. PMOs do not "touch" the TGF- $\beta 1$ gene also have an excellent safety profile. reatment of blood cancers. The treatment development of methods in the lab to while their maturation and ageing is

\section{Behind the Research}

\section{Dr Stephen Bartelmez}

E: sbartelmez@betastemtherapy.com T: $\quad$ +1-206-427-0350

\section{Research Objectives}

BetaStem Therapeutics aims to treat diabetic retinopathy own stem cells.

\section{Detail}

DrStephen Bartelmez

2 Lower Crescent Ave Suite 2 Sausalito

USA

Bio

Stephen Bartelmez, PhD, is the founder of BetaStem Therapeutics. He completed his immunology training at $U C$ Berkeley \& University of Glasgow and his stem cell training at Einstein College of Medicine, NYC. Following this, he sailed to Australia to work with Ray Bradley PhD, the father of modern blood stem cell research. Dr Bartelmez is a former member of faculty at Hutchinson Cancer Research Center, U. of Washington, ViaCell Inc. He founded BetaStem Therapeutics Inc. in 2006.

Funding

National Institute of Diabetes and Digestive and Kidney Diseases (NIDDK), National Heart, Lung, and Blood institute Dizabeth Barter

\section{Collaborators}

- Pat Iversen PhD

- Charlie Garcia MD

- Ewa Sitnicka PhD

- Carl Storey

\section{BetaStem}

\section{References}

Sitnicka E, Ruscetti FW, Priestley GV, Wolf NS, Bartelmez SH. (1996) Transforming growth factor beta 1 directly and reversibly inhibits the initial cell divisions of long-term 8. PubMed PMID: 8704205 . b.

Ruscetti FW, Bartelmez SH. (2001) Transforming growth ( 2001 Jul; 74(1):18-25. PubMed PMID: 11530800 c Ruscetti FW, Akel S, Bartelmez SH. (2005) Autocrine transforming growth factor-beta regulation of hematopoiesis. many outcomes that depend on the context. Oncogene. 200 Aug 29,24(37)5751.63. PubMed PMD: $16123808 . d$. Bhatwadekar AD, Guerin EP, Jarajapu YP, Caballero S,
Sheridan C, Kent D, Kennedy L, Lansang MC, Ruscetti FW, Pepine CJ, Higgins PJ Bartelmez SH, Grant MB (2010) Transient inhibition of transforming growth factor-beta 1 in human diabetic CD $34+$ cells enhances vascular reparative functions. Diabetes. Aug;59(8):2010-9. PubMed PMID: 20460428 PMID: 24223881, PubMed Central PMCID:

Bartelmez, S., Storey, C., Iversen, P., Ruscetti, F. (2016) Transient in and enhances multi-lineage repopulation efficiency. I Stem Cell Res Ther 1::00045 D01 $\mathrm{f}$

Patrick L. Iversen, Francis W. Ruscetti, Charles Garcia and Stephen H. Bartelmez (2018). Functional Activation of Autologous Human Diabetic Stem Cells for Cell Therapy, in press

\section{Personal Response}

What are your aspirations for BetaStem Therapeutics as a company over the next five years?

II We previously have had a "pre-IND" meeting with proceed with our first patient studies. With sufficien funding, our goal to test the safety and efficacy in diabetic patients with retinopathy looks sealistic. Dr Charlie Garcia for over four years and is helping design a clinical trial $H$ us has been working with patients with diabetic retinopathy for more than 40 years. Currently, there are no effective treatments, making this an important unmet need. So far,
the stem cells look promising. 